\title{
Internalisasi Nilai Multikultural untuk Memperkokoh Toleransi Umat Kristen Dan Muslim Di Kota Kupang
}

\section{Internalizing Multicultural Values To Strengthen Christian And Muslim Tolerance In Kupang City}

\author{
Moses Kollo ${ }^{1}$ \& Dixon Taek Bete ${ }^{2}$ \\ Program Studi Pendidikan Sejarah, FKIP Universitas Persatuan Guru 1945 NTT \\ Diterima: 17 September 2020 ; Direview: 26 September 2020 ; Disetujui:17 Oktober 2020 \\ moseskollo22@gmail.com
}

\begin{abstract}
Abstrak
Tulisan ini bertujuan untuk mendeskripsikan (1) Penyebab munculnya multikulturalisme agama (kristen dan Muslim) di Kota Kupang; (2) Bagaimana upaya Keluarga Kristen dan Muslim dalam menginternalisasikan nilai multicultural kepada setiap anak untuk memperkokoh toleransi antar umat beragama di Kota Kupang; dan (3) apa hasil dari peleburan masyarakat multikultur di Kota Kupang. Penelitian ini adalah deskriptif kualilatif dan kajiannya difokuskan pada interaksi sosial masyarakat Kristen dan Muslim di Kota Kupang. Data-data dikumpulkan menggunakan teknik wawancara, observasi dan studi pustaka kemudian di analisis secara kualitatif yang mencakup reduksi data, sajian data dan penarikan simpulan. Hasil kajian ini menyimpulkan bahwa (1) munculnya multikulturalisme agama (Kristen dan Muslim) disebabkan karena Kota Kupang merupakan pusat pemerintahan, perekonomian, pendidikan masyarakat NTT, dan perkawinan campur lintas agama dan etnis; (2) terdapat dua langkah oleh keluarga kristen dan muslim di Kota Kupang dalam menginternalisasi nilai multicultural kepada anak yakni mendidik dan mempraktekan langsung. Pertama, Mendidik, memberikan pemahaman kepada anak untuk senantiasa berjiwa gotong royong, komunikatif, toleran, menghargai, menghormati dan ramah terhadap sesama; kedua, Mempraktekan langsung yakni terlibat langsung dalam kegiatan sosial kemasyarakat seperti hajatan suka cita maupun duka cita; dan (3) "Beta Orang Kupang"merupakan peradaban baru yang muncul akibat meleburnya masyarakat Kota Kupang dari beragam latar belakang.

Kata Kunci: Multikulturalisme; Umat Kristen; Umat Muslim; Kota Kupang
\end{abstract}

\begin{abstract}
This paper aims to describe (1) the causes of the emergence of religious multiculturalism (Christian and Muslim) in Kupang City; (2) How are the efforts of Christian and Muslim families in internalizing multicultural values to each child to strengthen tolerance between religious communities in Kupang City; and (3) what is the result of the merger of multicultural societies in Kupang City. This research is a qualitative descriptive study and focuses on the social interactions of the Christian and Muslim communities in Kupang City. Data were collected using interview techniques, observation and literature study then analyzed qualitatively which includes data reduction, data presentation and drawing conclusions. The results of this study conclude that (1) the emergence of religious multiculturalism (Christian and Muslim) is due to the fact that Kupang City is the center of government, economy, education for the people of NTT, and inter-religious and ethnic mixed marriages; (2) there are two steps by Christian and Muslim families in Kupang City in internalizing multicultural values to children, namely directly educating and practicing. First, educating, giving understanding to children to always have the spirit of mutual cooperation, communicative, tolerant, respect, respect and friendly to others; second, direct practice, namely being directly involved in social activities in the community such as celebrating joy and sorrow; and (3) "Beta Orang Kupang" is a new civilization that emerged as a result of the fusion of the people of Kota Kupang from various backgrounds
\end{abstract}

Keywords: Multiculturalism; Christians; Muslims; Kupang City

How to cite: Kollo, M. \& Bete, D.T. (2020). Internalisasi Nilai Multikultural untuk Memperkokoh Toleransi Umat Kristen Dan Muslim Di Kota Kupang. Journal of Education, Humaniora and Social Sciences (JEHSS). 3 (2): 544-551

$5 \wedge 1$

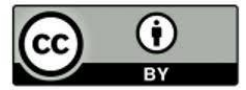

This work is licensed under a Creative Commons Attribution 4.0 


\section{PENDAHULUAN}

Multikulturalisme merupakan suatu paham yang secara tidak langsung membentuk karakter setiap orang untuk menerima sesamanya yang hidup dalam suatu komunitas sekalipun memiliki perbedaan identitas, bahasa, budaya yang dimiliki serta agama yang dianutnya sebagai suatu kesatuan untuk saling melengkapi dalam setiap aspek kehidupannya. Naim dan Sauqi (2008), multikulturalisme yaitu sebuah paham tentang kultur yang beragam. Dalam keragaman kultur ini meniscayakan adanya pemahaman, saling pengertian, toleransi, dan sejenisnya, agar tercipta suatu kehidupan yang damai dan sejahtera serta terhindar dari konflik berkepanjangan. Dalam konteks Indonesia, menurut Soyomukti (2015) bahwa paham multikulturalisme di Indonesia menjadi semarak kembali setelah masyarakat belajar dari pengalaman pahit dari diterapkannya politik monokulturalisme selama 32 tahun oleh kekuasaan Orde Baru. Salah satu contoh konkret dari praktek monokulturalisme adalah diskriminasi terhadap orang Tionghoa yang berkaitan dengan penyelenggaraan perayaan agama.

Salah satu cara yang dapat ditempuh untuk mewujudkan integrasi suatu masyarakat multikultural adalah dengan menanamkan nilai-nilai pluralisme. Upaya menanamkan nilai pluralisme dalam benak setiap anak bangsa sebagai pemegang tongkat kepemimpinan bangsa masa depan sudah harus dilakukan sejak dini yakni penerapannya melalui pendidikan keluarga sebagai sarana pendidikan nonformal. Sebab, pendidikan yang telah diberikan keluarga merupakan suatu fundamentalisme yang cepat membentuk karakter setiap anak kita, karena pendidikan yang telah diberikan tersebut tidak membutuhkan suatu perangkat akademik namun dapat dilangsungkan secara praktis dan dapat terjadi secara alami dan mudah untuk dipraktekkan. Karena pendidikan tersebut terjadi terus-menerus dalam keluarga maka kemudian menjadi suatu kebiasaan. Oleh karena itu, maka akan selalu melekat dalam diri anak dan selalu diingat dan dipegang menjadi suatu kebiasaan dan dapat dijadikan sebgai pedoman dalam kehidupan sehari-hari di manapun berada.

Kota Kupang merupakan ibu kota Provinsi Nusa Tenggara Timur yang didiami oleh penduduk dari beragam latar belakang agama, bahasa, adat istiadat, suku dan ras (masyarakat multikultural). Masyarakat Kota Kupang yang majemuk tersebut berasal dari daerah dan suku yang berbeda-beda seperti Timor, Helong, Flores, Sumba, Alor, Rote, Sabu, Bugis, Bali, Jawa dan Tionghoa. Meskipun berbeda dalam latar belakang, namun tetap menjunjung tinggi nilai toleransi dan selalu menerapkan sistem parsitipatif dan gotong royong dalam segala aspek kehidupan serta mengedepankan budaya santun di dalam berinteraksi antar umat beragama. Liliweri (2011) mengatakan bahwa untuk mencegah terjadinya disintegrasi, maka komunikasi (antarpribadi, kelompok, organisasi, publik, dan masa) bertujuan membangun makna-makna yang sama terhadap setiap pesan yang berfungsi menumbuhkan integrasi dan solidaritas antar suku bangsa.

Selain itu, yang paling terpenting dalam membangun sebuah komunikasi antar sesama untuk menciptakan sebuah iklim kehidupan yang harmonis adalah pentingnya toleransi antar sesama. Toleransi menurut Purwasito adalah upaya empati yakni upaya saling memahami secara sukarela dan terbuka. Sikap terbuka, sedia saling berbagi, kemauan berinteraksi dapat mendekatkan perbedaan ke persamaan serta banyak peluang untuk mengatasi hambatanhambatan (Suharyanto, 2017).

Meskipun demikian, penyebab terjadinya disintegrasi dalam kehidupan suatu masyarakat multikultural sering disebabkan oleh sebuah pemikiran etnosentrisme dan parokial yang bersifat narsisme yakni saling mengklaim oleh kelompok-kelopok orang tertentu bahwa budaya, agama, dan suku yang dimilikinya lebih baik dari pada yang dimiliki oleh kelompok lainnya. Pemikiran 
ini merupakan dasar dalam memecah suatu kelompok masyarakat yang hidup berdampingan dalam suatu komunitas dengan segala perbedaan yang dimiliki.

Untuk itu sangat jelaslah bahwa proses membudayakan toleransi dan santun tersebut harus dilakukan sejak dini. Karena itu, para keluarga sangat berperan penting di dalam proses penanaman nilai multikultural tersebut. Berdasarkan gambaran di atas maka, penelitian ini dipandang sangat penting untuk di lakukan. Adapun tujuan dari penelitian ini adalah untuk mendeskripsikan (1) Penyebab munculnya multikulturalisme agama (kristen dan Muslim) di Kota Kupang; (2) Bagaimana upaya Keluarga Kristen dan Muslim dalam menginternalisasikan nilai multicultural kepada setiap anak untuk memperkokoh toleransi antar umat beragama di Kota Kupang; dan (3) apa hasil dari peleburan masyarakat multikultur di Kota Kupang.

Penelitian ini memiliki relevansi dengan beberapa penelitian terdahulu yakni (1) penelitian Syahrul dan Arifin (2018) tentang Kebijakan Pendidikan Multikultur Pada Peserta Didik Non Islam Di Sekolah Muhammadiyah Kota Kupang. Penelitian ini menyimpulkan bahwa pendidikan multikultural tidak termuat dalam struktur kurikulum persekolahan tetapi dalam penerapannya, sekolah memiliki kebijakan dalam penerapannya. Wujud dari kebijakan ini adalah: tidak mewajibkan siswa perempuan dari agama lain untuk mengenakan jilbab dan memfasilitasi siswa yang beragama lain untuk memperoleh pelajaran agama sesuai agama yang di anut dengan menghadirkan guru agama sesuai agama yang dianutnya; (2) Penelitian Ani Sulianti (2018) berjudul Pendidikan Kewarganegaraan Dalam Budaya Multikultural Untuk Menanamkan Sikap Patriotisme Warga Negara. Penelitian ini menyimpulkan bahwa Budaya multikultural di Indonesia sangatlah beragam sehingga sangat mudah untuk mempengaruhi terbentuknya sikap patriotisme yakni menanamkan sikap rasa cinta tanah air sesorang melalui kemajemukan budaya yang dimiliki oleh suatu bangsa; dan (3) Penelitian Bagus Wahyu Setyawan (2019) tentang Metode Pembelajaran Berbasis Budaya Jawa Dalam Rangka Menykseskan Pendidikan Multikultural Di Era Revolusi Industri 4.0. Hasil penelitian ini mengungkapkan bahwa penggunaan budaya Jawa sebagai salah satu metode pembelajaran dipandang efektif untuk meperkuat karakter generasi muda Jawa untuk menghargai kearifan lokalnya yakni cinta budaya Jawa.

\section{METODE PENELITIAN}

Penelitian ini adalah deskriptif kualitatif. Moleong (2014) penelitian kualitatif adalah penelitian yang bermaksud untuk memahami fenomena tentang apa yang dialami oleh subjek penelitian misalnya perilaku, persepsi, motivasi, tindakan, dan lain-lain secara holistik, dan dengan cara deskripsi dalam bentuk kata-kata dan bahasa, pada suatu konteks khusus yang alamiah dan dengan memanfaatkan berbagai metode ilmiah. Adapun teknik pengumpulan data yang digunakan adalah wawancara, observasi dan studi pustaka. Dalam kegiatan wawancara, peneliti mewawancarai beberapa informan yang merepresentasi masyarakat penganut agama Kristen dan penganut agama muslim. Sedang teknik observasi digunakan untuk melihat relasi sosial keagaaman masyarakat Kristen dan Muslim di Kota Kupang. Sedangkan telaah dokumen dilakukan agar merelevansikan data temuan penelitian dengan teori hasil penelitian terdalu maupun perbedaannya. Selanjutnya data-data penelitian dapat dianalisis secara kualitatif. Menurut Miles \& Hubberman. (2014) terdapat tiga langkah dalam menganalisis data kualitatif yakni reduksi data, penyajian data dan penarikan kesimpulan atau verifikasi.

\section{HASIL DAN PEMBAHASAN}

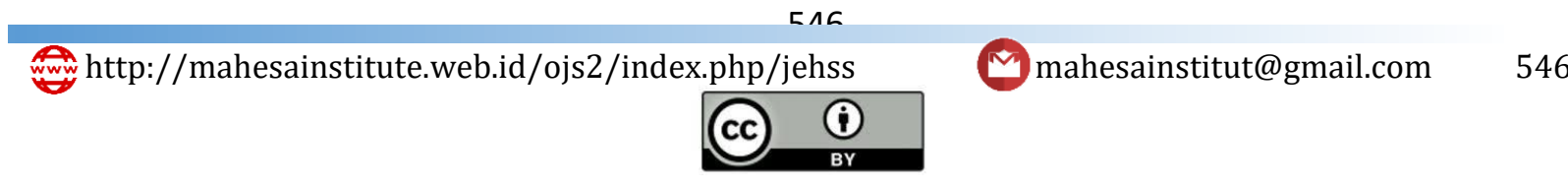

This work is licensed under a Creative Commons Attribution 4.0 
Kota Kupang merupakan Satu-satunya Kota yang berada di bagian Barat Pulau Timor dan menjadi ibu kota pemerintahan Provinsi Nusa Tenggara Timur. Berdasarkan data hasil penelitian dari badan pusat statistik (BPS) Kota Kupang ditemukan bahwa masyarakat Kota Kupang berjumlah 547.742 jiwa yang tersebar di 6 kecamatan yakni Kecamatan Alak, Maulafa, Oebobo, Kota Raja, Kelapa Lima dan Kota Lama dengan 51 kelurahan dan 1.324 RT, serta 423 RW yang tersebar di dalamnya. Dari sisi persebaran, dapat dilihat bahwa Kecamatan Oebobo memiliki jumlah penduduk paling tinggi yakni 152.246 atau sama dengan $23 \%$ dari total jumlah penduduk Kota Kupang. Sedangkan dari segi agama yang di anut, terdapat 5 agama yakni agama Protestan, Katolik, Islam, Hindu dan Budha. Dari data tersebut, agama Protestas memiliki jumlah penganut terbanyak yakni berjumlah 411.292 jiwa. Penduduk yang menganut agama Katolik berjumlah 81.390, kemudian agama Islam menempati urutan ketiga dengan jumlah penganut yakni berjumlah 51.143 jiwa. Namun pada konteks penlitian ini, peneliti selanjutnya menggabungkan jumlah penganut agama Protestan dan Agama Katolik dengan menyebutnya sebagai penganut "Agama Kristen" yang kemudian diakumulasikan jumlahnya menjadi 492.682 jiw penganut. Sehingga jumlah penganut agama Islam menjadi urutan ke dua dari total jumlah penduduk Kota Kupang dengan jumlah 51.143 jiwa penganut. Data tersebut dapat di bagi berdasarkan agama yang dianut per tahun 2017 dapat dilihat pada tabel berikut:

Tabel 1. sebaran penduduk Kota Kupang Berdasarkan Agama Yang di Anut tahun 2017

\begin{tabular}{clcccccc}
\hline \multirow{2}{*}{ No. } & $\begin{array}{c}\text { Nama } \\
\text { Kecamatan }\end{array}$ & \multicolumn{5}{c}{ Agama Yang Dianut } & \multirow{2}{*}{ Jumlah } \\
\cline { 2 - 7 } & Protestan & Katholik & Islam & Hindu & Budha & \\
\hline 1. & Alak & 56.354 & 3.993 & 12.551 & 89 & 17 & 73.004 \\
\hline 2. & Maulafa & 62.705 & 15.241 & 5.922 & 493 & 28 & 84.389 \\
\hline 3. & Oebobo & 113.025 & 26.879 & 10.631 & 1.670 & 41 & 152.246 \\
\hline 4. & Kota Raja & 46.711 & 9.788 & 5.589 & 498 & 42 & 62.628 \\
\hline 5. & Kelapa Lima & 80.666 & 20.036 & 8.243 & 824 & 45 & 109.814 \\
\hline 6. & Kota Lama & 51.831 & 5.453 & 8.207 & 128 & 42 & 65.661 \\
\hline Jumlah & $\mathbf{4 1 1 . 2 9 2}$ & $\mathbf{8 1 . 3 9 0}$ & $\mathbf{5 1 . 1 4 3}$ & $\mathbf{3 . 7 0 2}$ & $\mathbf{2 1 5}$ & $\mathbf{5 4 7 . 7 4 2}$ \\
\hline
\end{tabular}

Sumber: BPS Kota Kupang 2017

Data pada tabel 1 menunjukan bahwa jumlah penduduk Kota Kupang yang menganut Agama Kristen (Protestan dan Katolik) berjumlah 492.682 jiwa. sedangkan penduduk yang menganut agama Islam berjumlah 51.143 jiwa, Hindu berjumlah 3.702 jiwa dan Budha menempati posisi terakhir dengan jumlah 215 jiwa.

Berdasarkan hasil wawancara dari informan yang diambil dari perwakilah keluarga Kristen dan Keluarga Muslim di Kecamatan Alak, Maulafa, Oebobo, Kota Raja, Kelapal Lima, dan Kota Lama di Kota Kupang ditemukan hasil sebagai berikut: (1) munculnya multikulturalisme agama (Kristen dan Muslim) disebabkan karena Kota Kupang merupakan pusat, pemerintahan, perekonomian, dan pendidikan masyarakat NTT, dan perkawinan campur lintas agama dan etnis; (2) terdapat dua langkah yang digunakan oleh keluarga kristen dan muslim di Kota Kupang dalam menginternalisasi nilai multicultural kepada anak yakni mendidik dan mempraktekan langsung. Pertama, Mendidik, memberikan pemahaman kepada anak untuk senantiasa berjiwa gotong royong, komunikatif, toleran, menghargai, menghormati dan ramah terhadap sesama; kedua, Mempraktekan langsung yakni terlibat langsung dalam kegiatan sosial kemasyarakat seperti hajatan suka cita maupun duka cita; dan (3) "Beta Orang Kupang"merupakan peradaban baru yang muncul akibat meleburnya masyarakat Kota Kupang dari beragam latar belakang suku, agama, budaya dan bahasa daerah.

ธภフ 


\section{Penyebab Terbentuknya Multikulturalisme Agama di Kota Kupang}

Secara etimologis, multicultural berasal dari dua unsur kata yakni multi artinya banyak dan kultur artinya budaya. Jadi multicultural memiliki arti banyak budaya atau beragam budaya. Jadi yang dimaksud dengan multicultural adalah keberagaman suku, agama, etnis dan bahasa daerah yang dimiliki oleh sekelompok orang yang tinggal dalam suatu komunitas. Keberagaman ini perlu dipahami dan dijadikan sebagai suatu kekuatan dalam merajut kebersamaan yang harmonis. Sedangkan, bila kata multicultural berubah menjadi multikulturalisme, maka keberagaman latar belakang itu merupakan ideologi atau paham yang wajib ditanamkan atau diinternalisasi nilai-nilai yang terkandung di dalam keberagaman itu kepada seseorang agar dijadikan sebagai pedoman hidup untuk menjalin interaksi dalam suatu kelompok masyarakat yang memiliki beragam identitas.

Diketahui bahwa Kota Kupang terletak di Bagian Barat Pulau Timor dan menjadi pusat, perekonomian, pendidikan dan pemerintahan di Provinsi NTT dengan penduduk aslinya adalah masyarakat Suku Timor (Kabupaten Kupang dan Kota Kupang) dengan agama yang semula dianut adalah agama Protestan. Sedangkan penduduk yang menganut agama Katolik merupakan penduduk Kota Kupang yang berasal dari Kabupaten TTU (Suku Timor Dawan), Belu (Suku Tetun, Bunak dan Marae), dan Malaka (Suku Tetun dan Dawan). Sementara Penduduk Kota Kupang yang berasal pulau Sumba, Alor dan seluruh daratan Flores merupakan penduduk migran yang karena untuk tujuan pendidikan, dan ekonomi menyeberang dan menetap di Kota Kupang.

Sedangkan Penduduk muslim di Kota Kupang sebagian besar merupakan penduduk muslim yang berasal dari daerah Sulawesi, Jawa, Madura, Sumatra, Bali, Kalimantan dan bima serta daerah lain di Indonesia yang karena tujuan ekonomis dapat tinggal dan menetap di Kota Kupang. Adapun penduduk muslim di Kota Kupang yang berasal dari pulau Flores dan Alor, sering disebutnya sengan sebutan "muslim lokal" karena sudah berabad-abad tinggal di daerah NTT dan kemudian datang ke Kota Kupang yang tentunya dengan tujuan yang sama yakni melakukan usaha ekonomi, pendidikan dan bekerja pada instansi daerah.

Selain itu, multikulturalisme di Kota Kupang mendapat sumbangsih terbesar dari bidang pendidikan, sebab dengan tujuan meniti pendidikan seseorang yang tentunya dengan keberagaman latar belakang datang ke Kota yang berada di ujung barat pulau Timor dan kemudian tinggal menetap di Kota Kupang. Sedangkan menurut hasil penelitian Ichwan terhadap 12 etnik di Perumnas Kota Kupang (Liliweri, 2011) menyimpulkan bahwa pola pemukiman seperti perumnas merupakan pemukiman masa depan yang dapat di andalkan sebagai wadah peleburan budaya beragam etnik.

Berdasarkan data tersebut dapat disimpulkan bahwa tujuan pendidikan dan tujuan ekonomi merupakan penyebab terbentuknya suatu masyarakat multikultur. Di mana seseorang dapat mengunjungi suatu tempat dengan tujuan yang tentunya berbeda-beda. Meski demikian, multikulturalisme suatu kelompok masyarakat bias saja terjadi atas dasar asas kepentingan. Di mana, seseorang dengan terpaksa menerima dan menyesuaikan diri dengan identitas dan kebiasaan setempat karena semata-mata untuk melakukan aktifitas tertentu demi mencapai tujuan yang dicita-citakan. Namun hal ini, tak terkecuali untuk masyarakat Kota Kupang yang menerima keberagaman secara total tanpa ada muatan tertentu. Hal ini sebagaimana diungkapkan oleh Dhika Niti Prakasita \& Sugeng Harianto dalam artikelnya berjudul "MASYARAKAT MULTIKULTUR PERKOTAAN" (2017) mengatakan bahwa Masyarakat multikultur di perkotaan erat kaitannya dengan hubungan atau relasi antar individunya. Dalam kehidupan sehari-hari relasi sosial yang terjalin antar etnis melalui komunikasi, relasi sosial yang terjalin juga membawa dampak pada

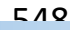


kegiatan ekonomi. Kegiatan ekonomi yang terjadi melibatkan dua pihak, yaitu pemilik usaha dengan anggotanya.

Selain itu, faktor lain yang sangat besar memberikan kontribusinya didalam memperkokoh paham multicultural di Kota Kupang adalah "perkawinan penduduk lintas agama dan lintas etnis". Contohnya, seorang Sulawesi beragama Muslim menikah dengan seseorang dari pulau Flores yang juga beragama Muslim. Hasil dari perkawinan ini akhirnya menggabungkan dua suku atau etnis dalam satu agama yakni muslim. Juga seseorang yang beragama Kristen dari suku Dayak di Kalimantan menikah dengan seseorang beragama Kristen dari suku Timor di NTT, akhirnya menghasilkan dua suku dalam satu keluarga Kristen. Begitu pula dua orang yang yang berasal dari suku Alor beragam Kristen dan Muslim saling mengawini dan memiliki keturunan yang menganut agama Muslim atau Kristen. Dari perkawinan ini kemudian muncul beragam agama dalam satu suku dan juga muncul beragam suku di dalam satu agama. Karena itu, kemudia lahir suatu kebudayaan baru yang dikatan sebagai budaya Kupang dengan segala pernik seperti "Bahasa Kupang dan Dialek Kupang". Perkawinan lintas agama dan suku tersebut dianggap sebagai poros baru perekat masyarakat multicultural di Kota Kupang.

\section{Dua Langkah Internalisasi Nilai Multikultural Kepada Diri Anak}

Pengakuan akan adanya keberagaman suku, budaya, agama dan etnis perlu mendapat apresiasi dari semua orang yang hidup dalam kelompok masyarakat tersebut. Untuk itu, nilai-nilai multikultural seperti gotong royong, toleran, saling menghormati, saling menghargai serta menerima sesama dari berbagai latar belakang suku, agama, etnis sebagai suatu kewajiban yang harus ditanamkan kepada pribadi anak oleh masing-masing keluarga sejak dini. Hal ini perlu dilakukan secara intensif, sehingga kebiasaan ini terus berakar dalam pribadi anak agar kelak menjadi modal dalam membangun relasi sosial dengan sesama manusia di lingkungan masyarakat di mana ia berada. Wujud dari internalisasi nilai multicultural kepada pribadi anak yang berlangsung secara baik dapat memberi sumbangsih terbesar bagi integrasi suatu bangsa multicultural serta dapat memperkokoh toleransi antar umat beragama. Akar dari nilai-nilai multikultural adalah toleransi. Sebab, toleransi menurut Suryana \& Rusdiana (2015) adalah membiarkan, menerima adanya perbedaan dalam waktu yang lama dan menjadi hak setiap warga Negara untuk diperlakukan setara tanpa memperhitungkan lagi latar belakang agama, etnisitas ataupun sifat-sifat spesifik yang dimiliki seseorang.

Demikian pula bagi masyarakat Kota Kupang, nilai-nilai multikutural seperti budaya gotong royong, toleran, menghargai perbedaan, peka, menerima akan adanya perbedaan, dan setia hidup berdampingan sudah ditanamakan kepada diri anak melalui pendidikan keluarga dan telah menjadi suatu kebiasaan yang sangat melekat. Selain itu, Proses internalisasi nilai multicultural ini juga dilakukan langsung oleh masing-masing keluarga secara nyata melalui praktek para orang tua dalam keseharian hidup sehari-hari. Sebab, menurut Kollo (2016) memahami pluralitas tidak hanya sebatas melihat keberagaman yang dimiliki oleh bangsa dan negara ini namun lebih dari itu kita dituntut untuk mengambil bagian dalam menanamkan nilai-nilai keberagaman tersebut dalam keseharian hidup kita, agar dapat tercipta bangsa yang besar dan harmonis. Hal-hal yang menjadi contoh praktek penerapan nilai multicultural bagi keluarga Kristen dan Muslim di Kota Kupang seperti, saling mengunjungi dan memberi ucapan salam serta saling membantu menyiapkan dan meminjamkan fasilitas dihari-hari besar keagamaan, juga dalam kegiata-kegiatan sosial kemasyarakatan. Adapun yang menjadi keunikan bagi masyarakat dalam menerapkan nilai multikulturalisme agama khususnya Kristen dan Muslim di Kota Kupang adalah: "Umat Muslim sering mengambil bagian dalam Karnaval perayaan paskah, mengatur parkiran kendaraan dan memberi ucapan salam kepada umat Kristen pada hari raya Natal dan Paskah". Hal serupa dilkukan 
oleh umat Kristen kepada umat Muslim adalah: "Umat Kristen memberikan kebebasan kepada umat muslim untuk mengadakan shalad sesuai waktunya, memberi ucapan salam dan membantu menyediakan tempat dan fasilitas lainnya yang dibutuhkan pada hari raya Idul Fitri dan hari raya besar lainnya". Selain itu, saling membantu dan berpartisipasi di setiap kegiatan sosial baik suka cita maupun duka cita merupakan hal Fasi yang telah berlangsung sejak dahulu kala. Penerapan nilai multikultur seperti ini mudah untuk dicerna dan ditiru oleh anak-anak usia dini. Tindakan ini merupakan amunisi yang dapat menembusi sekat perbedaan agama yang selalu menjadi hambatan komunikasi antar agama yang marak terjadi didaerah lain di Indonesia beberapa tahun belakangan ini. Karena itu, Purwasito (2015) mengatakan bahwa bendera agama atau aliran kepercayaan tidak dapat dipergunakan sebagai simbol interaksi, sebagai upaya menghindari perbenturan perbedaan konsep religius dan sentimen keagamaan yang tajam. Sedangkan (Naim dan Sauqi, 2008) mengatakan bahwa seorang baru dapat dikatakan menyandang sifat sebagai seorang pluralis apabila ia dapat berinteraksi secara positif dalam lingkungan kemajemukan tersebut.

\section{Beta Orang Kupang Sebagai Peradaban Baru}

"Beta Orang Kupang" merupakan suatu istilah yang lahir kemudian menjadi suatu kebudayaan baru akibat meleburnya masyarakat kota Kupang dengan segala perbedaan latar belakang yang dimiliki. Istilah ini dijadikan sebagai roh dan perekat untuk mempersatukan seluruh masyarakat Kota Kupang yang beragam. Di mana dengan kata tersebut seseorang tidak lagi dipandang berdasarkan agama, etnis dan suku yang dimilikinya serta dari mana ia berasal namun dapat dikenal sebagai seseorang yang berasal dari Kota Kupang. Istilah ini seakan menghantar masyarakat kota kupang akan sebuah pengakuan bahwa "Ia" juga merupakan masyarakat Kota Kupang yang memiliki hak dan kedudukan yang sama untuk mengaktualisasikan diri, menjalankan ibadah sesuai keyakinan, menjalankan momen adat istiadat sesuai tradisi, melaksanakan aktifikas perekonomian dan berhak menjalin hubungan antar sesama manusia serta memiliki hak yang sama untuk memperoleh perhatian dari pemerintah daerah. Selain itu, ciri khas seseorang dapat dikenal berasal dari kota Kupang adalah bias berkomunikasi menggunakan bahasa Kupang. Contoh kalimat Tanya: "Lu pu nama Siapa?" Jawab: Beta Anton!. Lu berarti "Kamu atau Anda", "Pu" berarti punya dan kata nama memeiliki pengertian yang sama yakni kata nama itu sendiri. Jadi kata ini mengandung pertanyaan "Kamu Bernama Siapa? Atau Siapa Nama Kamu? Sedangkan Beta memiliki arti "Saya" yang berarti "Saya Bernama Anton. Jadi sawabannya adalah "Saya Bernama Anton". Merujuk pada contoh kalimat percakapan terbut, maka seseorang dapat dikatakan berasal dari Kota Kupang (Orang Kupang) apabila bias berkomunikasi dengan seseorang baik bertanya maupun memberi jawaban menggunakan bahasa dan dialek Kota Kupang.

Proses sosial yang terjadi ini menunjukan adanya kesamaan derajad dan sebagai suatu kearifan yang dimiliki oleh masyarakat Kota Kupang yang jarang terjadi di daerah lain di Indonesia. Choirul Mahfud (2006) mengatakan bahwa multikulturalisme merupakan sebuah paham yang menekankan kesederajatan dan kesetaraan budaya-budaya lokal tanpa mengabaikan hak-hak dan eksistensi budaya lain.

\section{SIMPULAN}

Kota Kupang merupakan Pusat Pemerintahan, perekonomian dan pendidikan di Provinsi NTT, karena itu dapat mempertemukan banyak orang dari beragam latar belakang agama, suku, adat-istiadat dan budaya yang dimilikinya. Perbedaan latar belakang tidak menjadi sekat bagi masyarakat Kota Kupang untuk menjalin relasi sosial, namun mereka hidup sebagai saudara, saling menghargai, menghormati perbedaan, gotong royong dalam setiap hajatan sosial. Perbedaanperbedaan yang dimiliki tersebut kemudian melebur atau memadu dan dapat menghasilkan suatu 
peradaban atau budaya baru seperti muncul bahasa dan dialek Kota Kupang. Mereka yang telah lama tinggal di Kota Kupang yang ditandai dengan menggunakan bahasa dan dialek Kupang yang fasi kemudian menyebut dirinya dengan sebutan "Beta Orang Kupang" yang artinya "Saya Orang Kupang. Kebudayaan baru ini kemudian menjadi penting untuk diwariskan kepada generasi berikutnya yang ditandai dengan upaya masing-masing keluarga dalam menanamakan nilai keberagaman itu kepada setiap anak di dalam rumah tangga.

\section{DAFTAR PUSTAKA}

BPS Kota Kupang. (2020). Kota Kupang Dalam Angka 2020. Kupang: CV Idea.

Koentjaraningrat. 1974. Kebudayaan, Mentalitet dan Pembangunan. Jakarta: PT. Gramedia Pustaka Utama.

Kollo, M. (2016). Integrasi Pendidikan Multikultural dalam Pembelajaran Sejarah (Studi Kasus Pada SMA Kristen Mercusuar Kupang). Tesis: FKIP Universitas Sebelas Maret Surakarta.

Liliweri, A. (2011). Gatra-Gatra Komunikasi Antarbudaya. Yogyakarta: Pustaka Pelajar

Mahfud, C. (2006). Pendidikan Multikultural. Cetakan I. Yogyakarta: Pustaka Pelajar.

Miles \& Hubberman. (2014). Analisis Data Kualitatif. Terjemahan Tejetped Rohendi Rohidi. Universitas Indonesia (UI-Press).

Moleong, L, J. (2014) Metodologi Penelitian Kualitatif: edisi revisi. Bandung: PT Remaja Rosdakarya.

Naim, N., \& Sauqi, A. (2008). Pendidikan Multikultural: Konsep dan Aplikasi. Jogjakarta: AR-RUZZ MEDIA GROUP.

Prakasita, D.N. \& Harianto, S. (2017). Masyarakat Multikultur Perkotaan (Studi Relasi Antaretnis dalam Kegiatan Ekonomi di Wilayah Perak Surabaya). Jurnal: Paradigma, Volume 05, Nomor 03 Tahun 2017. Universitas Negeri Surabaya. https://media.neliti.com/media/publications/253166masyarakat-multikultur-perkotaan-studi-r-82f0e6a2.pdf.

Purwasito, A. (2015). Komunikasi Multikultural. Yogyakarta: Pustaka Pelajar.

Setyawan, B.W. (2019) Metode Pembelajaran Berbasis Budaya Jawa Dalam Rangka Menyukseskan Pendidikan Multikultural Di Era Revolusi Industri 4.0. JPK: Jurnal Pancasila dan Kewarganegaraan, Vol. 4 No. 3. Special Issue.

Soyomukti, N. (2015). Teori-teori Pendidikan: dari Tradisional, (neo) Liberal, Marxis-Sosialis, hingga Postmodern. Yogyakarta: Ar-Ruzz Media.

Suharyanto, A. (2017). Dilema Multikulturalisme Pada Masyarakat Multikultur Di Medan. Jurnal Kewarganegaraan 25 (PPKn, FIS, Universitas Negeri Medan), 118-127Sulianti, A. (2018). Pendidikan Kewarganegaraan Dalam Budaya Multikultural Untuk Menanamkan Sikap Patriotisme Warga Negara. JPK: Jurnal Pancasila dan Kewarganegaraan, Vol. 3 No. 2, Juli.

Suryana, Y \& Rusdiana, H. A. (2015). Pendidikan Multikultural, Konsep-Prinsip-Implementasi. Bandung: Pustaka Setia.

Syahrul dan Arifin. (2018). Kebijakan Pendidikan Multikultur Pada Peserta Didik Non Islam Di Sekolah Muhammadiyah Kota Kupang. JPK: Jurnal Pancasila dan Kewarganegaraan, Vol. 3 No. 2, Juli.

\section{$5[1$}

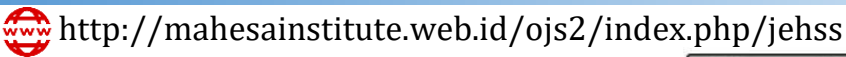

mahesainstitut@gmail.com 